\title{
Soluble urokinase-type plasminogen activator receptor and urokinase-type plasminogen activator receptor contribute to chemoresistance in leukemia
}

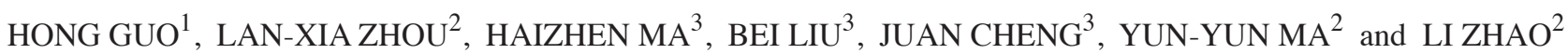 \\ ${ }^{1}$ Critical Care Medicine Department, ${ }^{2}$ Central Laboratory; ${ }^{3}$ Department of Hematology, \\ The First Affiliated Hospital, Lanzhou University, Lanzhou, Gansu 730000, P.R. China
}

Received October 10, 2015; Accepted February 23, 2017

DOI: $10.3892 / \mathrm{ol} .2017 .6150$

\begin{abstract}
The soluble urokinase-type plasminogen activator receptor (suPAR) and the urokinase-type plasminogen activator receptor (UPAR) have been proposed as useful biomarkers of tumor progression. Recently, suPAR was associated with chemoresistance in lung cancer. However, its clinical significance in leukemia has not previously been investigated. The present study examined the plasma levels of suPAR and the expression of the UPAR on bone marrow (BM) cells in 86 patients with leukemia at diagnosis prior to chemotherapy and 26 normal subjects (control group). The plasma suPAR levels were measured using ELISA, whilst uPAR expression was assayed by flow cytometry analysis. In addition, cell surface UPAR expression on K562 and multidrug-resistant K562/ADM cell lines was studied by western blotting. On admission and follow-up, the levels of suPAR in patients with leukemia were significantly increased compared with controls. Systemic levels of suPAR were strongly associated with the numbers of white blood cells. A case was defined as uPAR-positive $\left(\mathrm{uPAR}^{+}\right)$if $>20 \%$ of the gated cells expressed UPAR. In comparison with 26 healthy BM samples that were negative for UPAR expression, 48 (55.8\%) of the 86 leukemia patients were uPAR ${ }^{+}$. uPAR expression on the cell surface of multidrug-resistant K562/ADM cells was increased compared with that on K562 cells. In conclusion, plasma suPAR expression may be a useful marker for subtype classification of patients with leukemia and cell surface uPAR may be associated with resistance to chemotherapy or disease progression.
\end{abstract}

Correspondence to: Miss Li Zhao, Central Laboratory, The First Hospital of Lanzhou University, 1 Donggang West Road, Lanzhou, Gansu 730000, P.R. China

E-mail: gszhaoli66@163.com

Key words: uPAR, leukemia, chemoresistance

\section{Introduction}

Urokinase plasminogen activator receptor (UPAR) is a receptor which is mainly expressed on various immunologically-active cells including macrophages, neutrophils, activated T lymphocytes and as endothelial cells. UPAR performs an important role in plasminogen activation, cell adhesion and migration- all central aspects of inflammatory processes, and numerous disease prognoses (1). suPAR, the soluble form of UPAR, has emerged as a valuable indicator of the activation state of the immune system. suPAR is detectable in low, but constant concentrations in the plasma of healthy individuals $(2,3)$. Increased suPAR levels have been observed in numerous pathological conditions including infection (4-6), autoimmune diseases $(7,8)$ and neoplastic diseases (9), as well as during pregnancy (10) and pregnancy-associated disorders $(11,12)$. Preliminary studies indicate that increased plasma suPAR concentrations were observed in patients with non-small-cell lung (13), advanced breast and colorectal (14) and ovarian cancer (15). In ovarian cancer, high preoperative levels of suPAR were associated with a decreased survival rate (15). The association between increased plasma suPAR and increased mortality has also been documented in patients with HIV (16) and sepsis (17). suPAR is considered to be a marker of disease severity and risk of mortality in a heterogeneous cohort of patients with a variety of diseases (18-20). The independent prediction of clinical outcome by suPAR suggests it could be of value in prognostic algorithms (20).

Mustjoki et al (21) first reported the plasma soluble urokinase receptor in acute leukemia patients in 1999, and the results suggested that cell surface uPAR may also be a useful marker for leukemia subclassification, and that high level of plasma suPAR were associated with resistance to chemotherapy in acute myeloid leukemia (AML). However, a clinical study by Graf et al (22) suggested that cases with increased proportions of uPAR-positive $\left(\mathrm{uPAR}^{+}\right)$cells were characterized by a significantly lower remission rate to AML-cooperative group therapy and an increased risk for relapse. Evaluation of leukemic relapse is difficult and thus early clinical intervention is often delayed. The prognostic value of plasminogen activation in patients with leukemia has been difficult to assess as there have been few studies on leukemia patients and those reported studies used small 
cohort of patients. To overcome these weaknesses, the present study analyzed both cell surface and plasma compartments of blood samples from patients with leukemia, investigated the association between markers of plasminogen activation and the treatment response.

\section{Materials and methods}

Study subjects. Patients who were admitted to the Hematology Department at the First Affiliated Hospital, Lanzhou University (Lanzhou, China) between 1 September 2013 and 1 August 2014 were enrolled in the present study. Approval for the present study was obtained from the hospital Ethics Committee of the First Affiliated Hospital, Lanzhou University, and written informed consent was obtained from each patient prior to the start of the study. Bone marrow aspiration and other diagnostic procedures were performed at admission. A pathological diagnosis was made on the third day subsequent to admission. Diagnosis and classification of the leukemia cases were based on morphology, cytochemistry and flow cytometry according to World Health organization and French-American-British (FAB) classifications (5). The morphological evaluation was based on the presence of maturation and differentiation antigens as determined by routine immunophenotyping criteria of the European Group for the Immunological Characterization of Leukemia's (6). On the fourth day subsequent to admission, chemotherapy was administered. Blood and bone marrow samples were obtained from patients prior to chemotherapy. A total of 86 patients with leukemia and 26 healthy volunteers were enrolled in the present study.

Sample analysis. Levels of suPAR expression were determined using ELISA (cat. no. LYD12482) and based on protocols from manufacturer (ViroGates A/S, Birkerød, Denmark). The absorbance of samples was measured at $450 \mathrm{~nm}$ using a VERSAmax Tunable Microplate Reader (Molecular Devices, LLC, Sunnyvale, CA, USA). ELISA results were measured in nanograms per milliliter $(\mathrm{ng} / \mathrm{ml})$.

Flow cytometry analysis. The bone marrow cells $\left(1 \times 10^{6} \mathrm{cells} / \mathrm{ml}\right)$ were collected from the patients and placed in two anticoagulant tubes deposited with EDTA. One tube was added with $5 \mu 1$ corresponding control antibodies (neat, mouse IgG1 APC; no. 5146606; eBioscience, Inc., San Diego, CA, USA,), and the other tube was added with $5 \mu 1$ of the mouse monoclonal uPAR antibody (neat, no. 17-3879-4; eBioscience, Inc.). Intracellular staining for uPAR expression was performed by means of allophycocyanin. Subsequent to incubation in a black room at room temperature, cells were washed with PBS twice and 10,000 cells were analyzed with a FACScan by the BD FACSDiva software version 7.0 (BD Biosciences, Franklin Lakes, NJ, USA).

Cell culture. Leukemia cell lines, sensitive K562 and multidrug-resistant K562/ADM, were obtained from the Central Laboratory of the First Affiliated Hospital, Lanzhou University and cultured in RPMI-1640 medium supplemented with $10 \%$ fetal bovine serum (FBS), in a humidified atmosphere with $5 \% \mathrm{CO}_{2}$ at $37^{\circ} \mathrm{C}$.
Western blotting. To analyze protein expression in the cells and culture supernatants, cells were cultured for $48 \mathrm{~h}$. For cellular membrane proteins, the cells were washed with ice cold PBS and then extracted with lysis buffer at $4^{\circ} \mathrm{C}(50 \mathrm{mM}$ Tris- $\mathrm{HCl}, 150 \mathrm{mM} \mathrm{NaCl}, 1 \mathrm{mM}$ EDTA, $0.1 \%$ sodium dodecyl sulfate, $0.5 \%$ deoxycholic acid, $0.02 \%$ sodium azide, $1 \% \mathrm{NP}-40,2.0 \mathrm{mg} / \mathrm{ml}$ aprotinin and $1 \mathrm{mM}$ phenylmethylsulfonyl fluoride) supplemented with Complete Protease Inhibitor Cocktail tablets (Roche Diagnostics, Tokyo, Japan). Following storage on ice for $30 \mathrm{~min}$ at $4^{\circ} \mathrm{C}$, the lysates were centrifuged at $20,000 \mathrm{x}$ g for $30 \mathrm{~min}$ at $4^{\circ} \mathrm{C}$ and the supernatants (soluble proteins) were collected. The protein concentration was measured using Pierce $660 \mathrm{~nm}$ Protein Assay (Pierce; Thermo Fisher Scientific, Inc., Waltham, MA, USA). Subsequent to each sample being mixed 1:1 with $5 \mathrm{X}$ Laemmli sample buffer (Bio-Rad Laboratories, Inc., Hercules, CA, USA) and boiled for $5 \mathrm{~min}, 20 \mu \mathrm{g}$ of protein were separated using 7\% SDS-PAGE. The proteins were transferred to polyvinylidene fluoride membranes (ATTO Corporation, Tokyo, Japan) by electroblotting, blocked with TBS (pH 7.4) with $0.05 \%$ Tween-20, and supplemented with $0.3 \%$ non-fat dry milk for $1 \mathrm{~h}$ at room temperature (RT). The membranes were next incubated overnight at $4^{\circ} \mathrm{C}$ with primary antibodies against uPAR [no. 17-3979; dilution, 1:1,000 in TBST (TBS-Tween-20)]. Following extensive washing with TBST, the membranes were incubated for $1 \mathrm{~h}$ at RT with peroxidase-conjugated anti-mouse secondary antibodies (no. A7851; dilution, 1:100,000 in TBST Sigma-Aldrich; Merck KGaA, Darmstadt, Germany). $\beta$-actin was used as the internal control. The signals were visualized using an LAS-3000 Image Analyzer (Fujifilm, Tokyo, Japan) subsequent to the membranes being incubated with the ECL Prime Western Blotting Detection reagent (GE Healthcare Bio-Sciences, Pittsburgh, PA, USA) for $5 \mathrm{~min}$ at room temperature.

RNA isolation and reverse transcription-quantitative polymerase chain reaction ( $R T-q P C R)$. Total RNA was extracted with TRIzol reagent supplied by Sigma-Aldrich (Merck KGaA; no. T9424) according to the manufacturer's protocol, then the RNA was removed using RNases supplied by Sigma-Aldrich (Merck KGaA; no. R6513) and reverse transcribed using a SuperScript III First-strand synthesis system (Invitrogen; Thermo Fisher Scientific, Inc.) to generate cDNA according to the manufacturer's protocol. PCR was performed using a LightCycler 480 SYBR-Green I Master (Roche Diagnostics, West Sussex, UK) according to the manufacturer's protocol. Transcription of $\beta$-actin was examined with the primers 5'-TGGCACCCAGCACAATGAA-3' and 5'-CTAAGTCAT AGTCCGCCTAGAAGCA-3. Primers for uPAR were 5'-AAC AGTGCCTGGATGTGGTG-3' and 5'-GAAGTGGAAGGT GTCGTTGTTG-3'. Subsequent to the initial denaturation step of $5 \mathrm{~min}$ at $95^{\circ} \mathrm{C}, 40$ cycles of amplification for each primer pair were carried out. Each cycle consisted of: Denaturation, $10 \mathrm{sec}$ at $95^{\circ} \mathrm{C}$; annealing, $20 \mathrm{sec}$ at $60^{\circ} \mathrm{C}$; and elongation, $10 \mathrm{sec}$ at $72^{\circ} \mathrm{C}$. Final elongation temperature was $65^{\circ} \mathrm{C}$ for $1 \mathrm{~min}$. Relative levels of gene expression was measured using a LightCycler 480 (Roche Diagnostics) according to the manufacturer's protocol. The relative changes in the expression levels of uPAR genes were normalized using the $2^{-\Delta \Delta \mathrm{Cq}}$ method against the level of $\beta$-actin gene expression in each 
sample. Experiments were carried out at least in duplicate for each data point (23).

Statistical analysis. A descriptive statistical analysis was performed for all biological variables. Data obtained to measure the normal distribution were analyzed using the Kolmogorov-Smirnov test. Data in conformity with normal distribution were analyzed using the Student's t-test and those not conforming to normal distribution were analyzed using the Mann-Whitney U test. Results obtained by measurements are presented as the mean \pm standard deviation. The area beneath the receiver operating characteristics (ROC) curve was used to calculate the discriminative ability of suPAR to determine patients following chemotherapy. Sensitivity, specificity, negative predictive values, and positive predictive values were calculated for these markers on the basis of ROC curves. $\mathrm{P}<0.05$ was considered to indicate a statistically significant difference.

\section{Results}

Baseline data. Within the enrollment period, 86 patients were included in the present study. The patients' baseline characteristics are summarized in Table I. The subjects comprised of $66.3 \%$ men, and the median age was 43.8 years. Acute leukemia was subsequently diagnosed in 76 of these patients: 51 subjects had AML (FAB classes, M1: 5; M2: 7; M3: 9; M4: 13; M5: 12; and M6: 5); and 25 subjects had acute lymphocytic leukemia (ALL). A total of 6 subjects had chronic myeloid leukemia (CML) and 4 subjects had chronic lymphocytic leukemia (CLL). The diagnoses were based on morphological, cytochemical, cytogenetic and cell surface marker expression. Blood samples from 26 healthy volunteers were used as controls. The median suPAR level was $3.38 \mathrm{ng} / \mathrm{ml}$ (range, 1.89 to $8.32 \mathrm{ng} / \mathrm{ml}$ ) in patients with leukemia. In control subjects the median suPAR level was $2.76 \mathrm{ng} / \mathrm{ml}$ (range, 1.63 to $2.91 \mathrm{ng} / \mathrm{ml}$ ), which was statistically significant compared with patients with leukemia $(\mathrm{P}<0.05)$. There was no association between sex and plasma suPAR concentration $(\mathrm{P}>0.05)$ in patients with leukemia. The median uPAR expression rate was $36.2 \%$ in patients with leukemia, and $18 \%$ was observed in healthy adults.

Subtypes of leukemia exhibit different suPAR levels. Plasma levels of suPAR were elevated in patients with leukemia compared with healthy subjects. In all subtypes of leukemia, the suPAR value was increased compared with chronic leukemia patients $(3.53 \pm 1.15 \mathrm{vs} .2 .27 \pm 0.36 \mathrm{ng} / \mathrm{ml} ; \mathrm{P}<0.05)$ and suPAR values of AML were increased compared with ALL $(3.93 \pm 1.16$ vs. $2.69 \pm 0.53 \mathrm{ng} / \mathrm{ml} ; \mathrm{P}<0.05)$. Patients with AML had significantly increased plasma levels of suPAR compared with other group leukemia patients, $2.44 \pm 0.31 \mathrm{ng} / \mathrm{ml}$ in CML $(\mathrm{P}<0.05) ; 2.02 \pm 0.11 \mathrm{ng} / \mathrm{ml}$ in CLL $(\mathrm{P}<0.05$; Fig. 1).

In all subtypes of the 51 patients with AML, suPAR values were measured as follows: M1 $(\mathrm{n}=5,2.62 \pm 0.34 \mathrm{ng} / \mathrm{ml}) ; \mathrm{M} 2$ $(\mathrm{n}=7,3.65 \pm 0.88 \mathrm{ng} / \mathrm{ml}) ; \mathrm{M} 3(\mathrm{n}=9,5.11 \pm 1.45 \mathrm{ng} / \mathrm{ml}) ; \mathrm{M} 4(\mathrm{n}=13$, $3.64 \pm 0.65 \mathrm{ng} / \mathrm{ml}) ; \mathrm{M} 5(\mathrm{n}=12,4.58 \pm 0.74 \mathrm{ng} / \mathrm{ml})$; and M6 $(\mathrm{n}=5$, $2.78 \pm 0.2 \mathrm{ng} / \mathrm{ml}$ ). As shown in Fig. 2, the levels of suPAR in M3 and M5 were increased compared with other subtype groups $(\mathrm{P}<0.005)$.
Table I. Baseline characteristics of the study cohort.

\begin{tabular}{lcc}
\hline Variable & $\begin{array}{c}\text { Leukemia } \\
\text { patients }\end{array}$ & $\begin{array}{c}\text { Healthy control } \\
\text { individuals }\end{array}$ \\
\hline Number & 86 & 26 \\
Age (years) & $43.8(12-70)$ & $44.6(35-55)$ \\
Gender (male/female) & $57 / 29$ & $19 / 7$ \\
Type of leukemia & & \\
AML & 51 & \\
ALL & 25 & \\
CML & 6 & \\
CLL & 4 &
\end{tabular}

Chemotherapy protocol

Induction

$64(74.4 \%)$

Consolidation

$\operatorname{suPAR}(\mathrm{ng} / \mathrm{ml})$

3.38

2.76

$\mathrm{uPAR}^{+}(\%)$

$36.2 \%$

$18 \%$

AML, acute myeloid leukemia; ALL, acute lymphocytic leukemia; CML, chronic myeloid leukemia; CLL, chronic lymphocytic leukemia; suPAR, soluble urokinase-type plasminogen activator receptor; uPAR, urokinase-type plasminogen activator receptor.

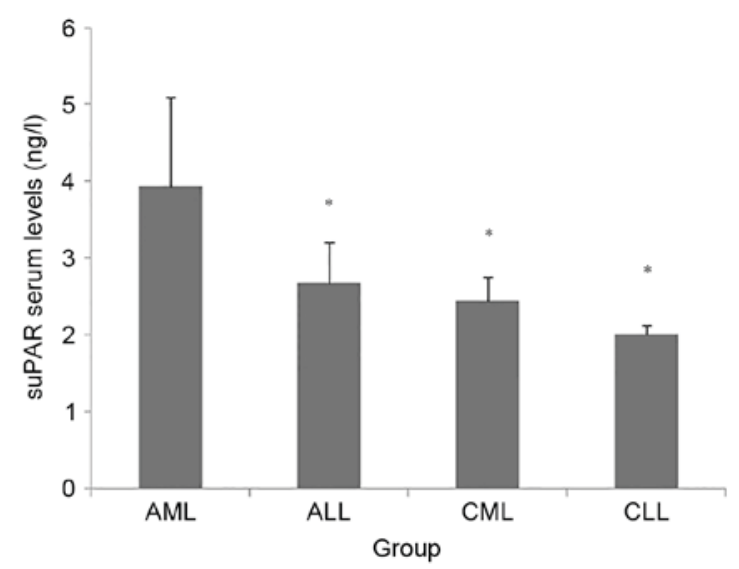

Figure 1. Differentiated subtype leukemia demonstrated different suPAR levels according to acute or chronic and myeloid or lymphoblastic cells. ${ }^{*} \mathrm{P}<0.05$ vs. AML (t-test). suPAR, soluble urokinase-type plasminogen activator receptor; AML, acute myeloid leukemia; ALL, acute lymphocytic leukemia; CML, chronic myeloid leukemia; CLL, chronic lymphocytic leukemia.

The present study additionally subdivided the patients based on age using 10-year intervals and assessed suPAR levels in different age groups. As shown in Fig. 3, suPAR levels in patients $<20$ years old were reduced compared with older patients. There was no association between other age groups and plasma suPAR concentration $(\mathrm{P}>0.05)$. Analysis of suPAR levels using the ROC revealed the area under the curve to be 0.871 (Fig. 4).

Differentiated type leukemia shows different $u P A R$ expression. The present study assessed cellular UPAR expression- if the percentage of positive events was $>20 \%$, the sample was 
Table II. Correlations of uPAR and suPAR with clinical parameters.

\begin{tabular}{|c|c|c|c|c|c|c|c|c|c|c|}
\hline \multirow[b]{2}{*}{ Variant } & \multirow[b]{2}{*}{ Patients } & \multicolumn{3}{|c|}{ uPAR expression } & \multicolumn{3}{|c|}{ suPAR expression } & \multicolumn{3}{|c|}{ uPAR and suPAR expression } \\
\hline & & Positive & Negative & P-value & Positive & Negative & P-value & Co-positive & Co-negative & P-value \\
\hline Gender & 86 & 48 & 38 & 0.568 & 32 & 54 & 0.188 & 21 & 65 & 0.269 \\
\hline Male & 57 & 33 & 24 & & 24 & 33 & & 16 & 41 & \\
\hline Female & 29 & 15 & 14 & & 8 & 21 & & 5 & 24 & \\
\hline Age & & & & 0.06 & & & 0.256 & & & 0.727 \\
\hline$>50$ & 21 & 8 & 13 & & 10 & 11 & & 5 & 16 & \\
\hline$<50$ & 65 & 40 & 25 & & 22 & 43 & & 18 & 47 & \\
\hline Type & & & & 0.118 & & & 0.048 & & & 0.023 \\
\hline AML & 51 & 32 & 19 & & 30 & 21 & & 24 & 27 & \\
\hline NAML & 35 & 16 & 19 & & 10 & 25 & & 8 & 27 & \\
\hline Response & & & & 0.046 & & & 0.094 & & & 0.032 \\
\hline Good & 45 & 20 & 15 & & 13 & 32 & & 10 & 35 & \\
\hline Poor & 41 & 27 & 14 & & 19 & 22 & & 18 & 23 & \\
\hline
\end{tabular}

uPAR, urokinase-type plasminogen activator receptor; suPAR, soluble urokinase-type plasminogen activator receptor; AML, acute myeloid leukemia; NAML, non-acute myeloid leukemia.

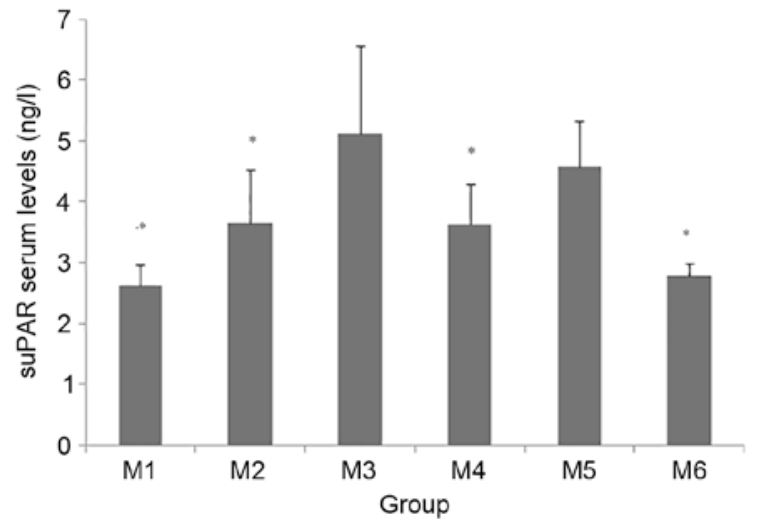

Figure 2. Differentiated AML subtype demonstrated different suPAR levels. ${ }^{*} \mathrm{P}<0.05$ vs. M3 and M5 (t-test). AML, acute myeloid leukemia; suPAR, soluble urokinase-type plasminogen activator receptor.

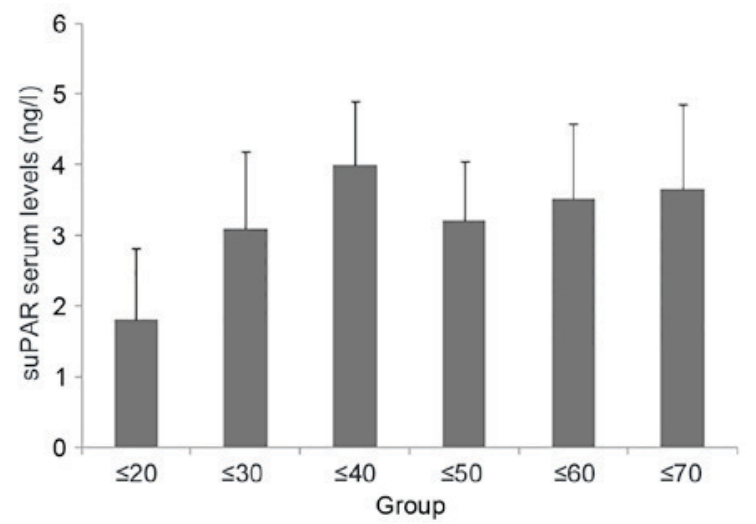

Figure 3. Differentiated age leukemia patients demonstrated different suPAR levels. Data are shown as means \pm standard error of the mean. uPAR values in $\leq 20$ years old patients were lower other groups $(\mathrm{P}<0.05)$. There was no association between other age groups with plasma suPAR concentration $(\mathrm{P}>0.05)$. suPAR, soluble urokinase-type plasminogen activator receptor.

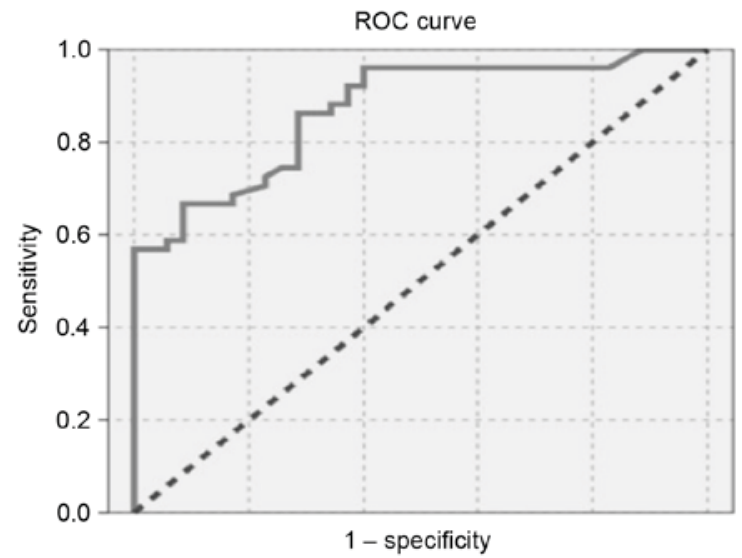

Figure 4. Analysis of suPAR levels using the ROC curve method on AML diagnosis. The area under the curve was 0.871 . suPAR, soluble urokinase-type plasminogen activator receptor; ROC, receiver operating characteristics; AML, acute myeloid leukemia.

considered to be positive for that surface marker. Flow cytometry analysis demonstrated that while $80 \%$ of leukemia samples studied were $\mathrm{UPAR}^{+}$, none of the healthy samples were uPAR $^{+}$(Fig. 5).

Correlations of UPAR and SUPAR with leukemia clinical parameters. Patients were divided into two groups according to the suPAR expression level (> vs. <; mean value, $3.38 \mathrm{ng} / \mathrm{ml}$ ). The difference between these groups was calculated with the $\chi^{2}$ test. The good response group was defined as those demonstrating complete remission with 1-2 cycles of chemotherapy and no relapse within five months; and the poor response group was those having residual disease subsequent to $\geq 2$ cycles of chemotherapy, patient mortality or relapse during therapy (within five months). As demonstrated in Table II, the treatment response of the UPAR and suPAR co-expression group 

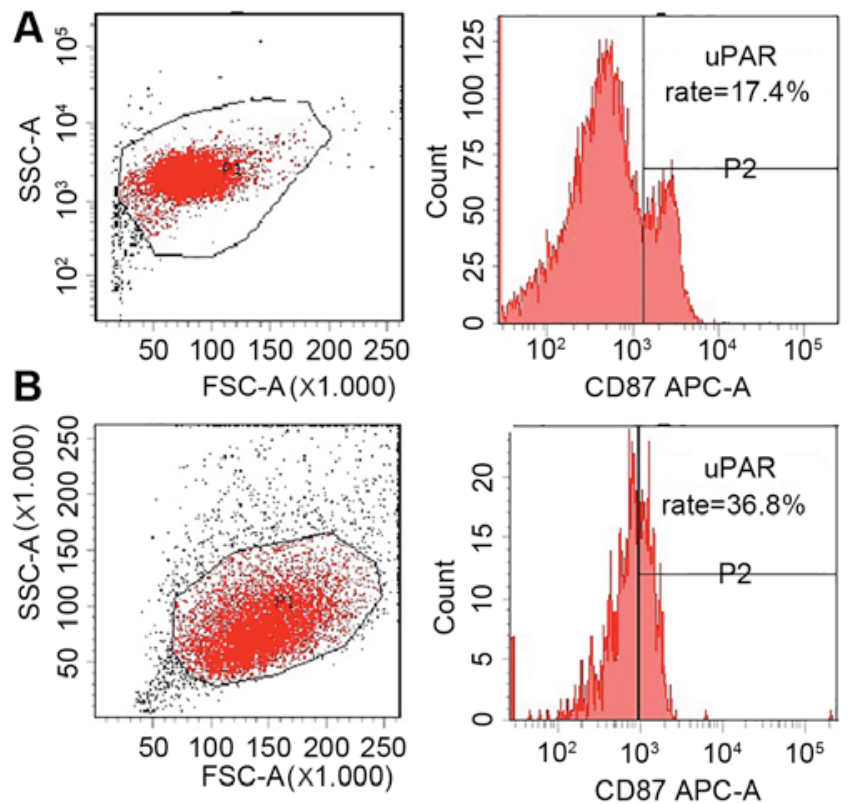

Figure 5. Flow cytometry analysis of surface uPAR expression. The healthy samples were uPAR $^{-}\left(17.4 \%\right.$, see A), and leukemia samples were uPAR $^{+}$ (36.8\%, see B). uPAR, urokinase-type plasminogen activator receptor; SSC, side scatter; FSC, forward scatter; CD, cluster of differentiation; APC, allophycocyanin.

was significantly increased compared with that of the negative uPAR and/or suPAR expression group $(\mathrm{P}=0.032$ vs. $\mathrm{P}=0.026$, $\mathrm{P}=0.034)$. uPAR and suPAR co-expression and suPAR single positive expression was associated with the AML type (respectively, $\mathrm{P}=0.032, \mathrm{P}=0.048$ ). No significant difference was observed between UPAR or suPAR single positive groups and the clinical parameters studied.

Overexpression of UPAR in the multidrug-resistant leukemia K562/ADM cell line. The leukemia sensitive and multidrug-resistant cells lines (K562 and K562/ADM, respectively) were selected for evaluation. Cell surface localization of UPAR was verified by western blotting of cell membrane fractions. K562/ADM cell surface exhibited increased expression of uPAR compared with K562, as shown by western blotting (Fig. 6). RT-qPCR mRNA analysis additionally confirmed these results.

\section{Discussion}

The present study investigated whether plasma level of suPAR or cell surface expression UPAR was associated with leukemia pathogenesis and treatment response. The results demonstrated that suPAR was significantly elevated in the plasma of patients with acute myeloid leukemia. However, uPAR was identified on the surface of leukemic blasts in both myeloid and lymphoid leukemia patients. Secondly, high levels of suPAR and positive surface UPAR expression were associated with decreased chemosensitivity in the leukemic cells. Thirdly, uPAR expression level on multidrug-resistant K562/ADM cell surface was increased compared with that on the sensitive K562 cell surface.

Previous studies have demonstrated that suPAR was associated with cancer development, and was also an important
A

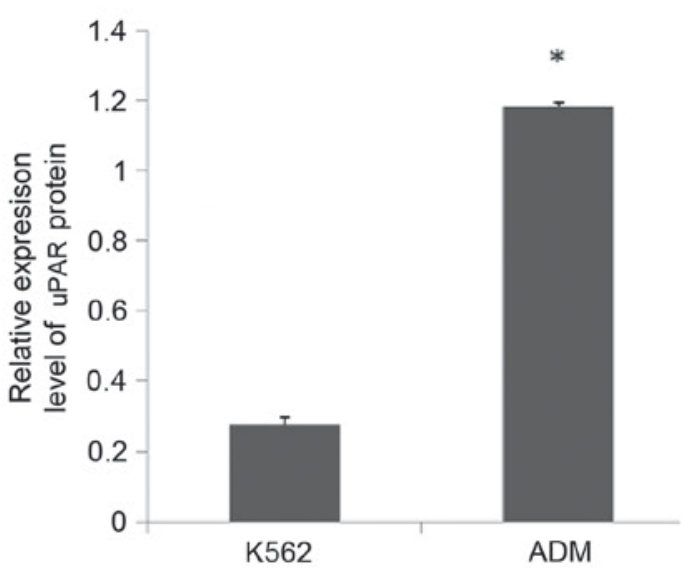

B
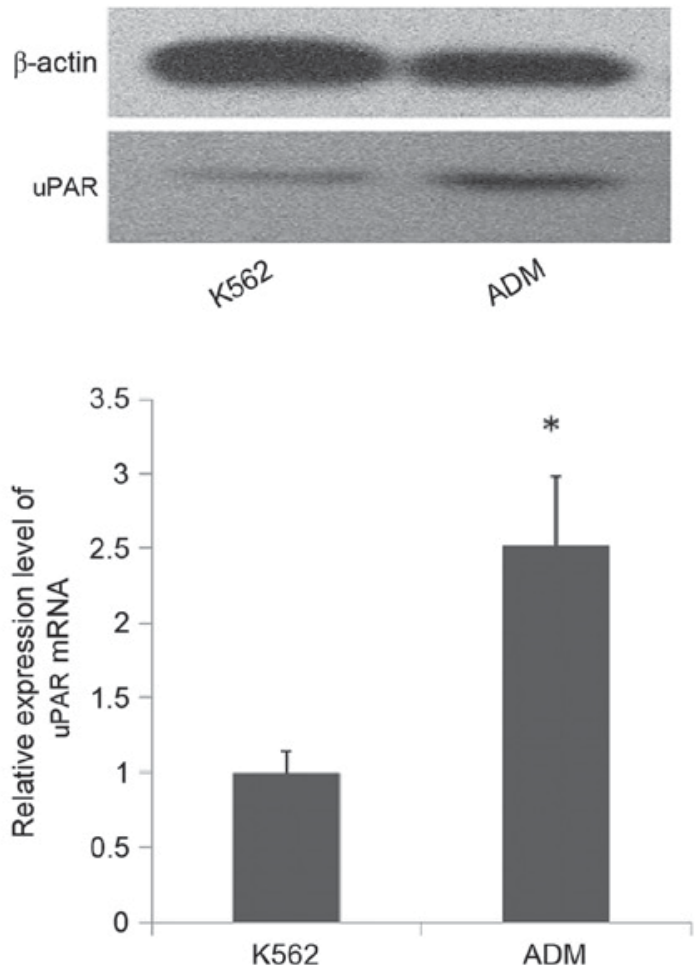

Figure 6. (A) Western blotting of cellular membrane fractions using a polyclonal anti-murine uPAR antibody (Clone AF534). $\beta$-actin was used as the control. (B) Relative Plaur mRNA (uPAR) expression levels as analyzed using reverse transcription-quantitative polymerase chain reaction. Error bars represent the standard error of means \pm standard error of the mean and $\mathrm{n}=3$. t test; ${ }^{*} \mathrm{P}<0.05$. uPAR, urokinase-type plasminogen activator receptor.

biomarker reflecting disease severity, and mortality in a variety of diseases (24-26). Kaya et al revealed that suPAR was an important and sensitive biomarker that could predict infection status in an early stage of febrile neutropenia, and for patients with hematologic malignancies (27). The results of the present study demonstrated that high levels of suPAR were associated with decreased chemosensitivity in leukemic cells and patients.

UPAR is expressed in differentiated myeloid cells, but not in cells exhibiting lymphoid markers (18). The immature hematopoietic cells, including cluster of differentiation (CD) $34^{+}$progenitor cells, and less differentiated bone marrow cells do not express UPAR (18). In the bone marrow, uPAR has been identified in mature monocytes, however not 
in red blood cells, erythroblasts or platelets (28). The present results indicate that leukemic blasts, M0-M5 of AML, express UPAR on the cell surface. The levels of soluble UPAR were elevated in the plasma of acute leukemia patients. UPAR expression is often increased in high grade and late stage tumor cells, suggesting that UPAR may have a role related to invasion and metastasis. The present study revealed that patients with low levels of UPAR demonstrated improved chemosensitivity compared with patients with high uPAR expression. Similar results were also observed in patients with differential suPAR expression. These results indicated that chemosensitivity of leukemic cells were inseparably linked with uPAR expression in vivo. Previous studies have demonstrated that the promyelocytic NB4 cells expressed uPAR on its cell surface (21). In small-cell lung cancer cell lines, $\mathrm{uPAR}^{+}$cells were more resistant to chemotherapeutic drug treatment compared with uPAR $^{-}$cells (24). Indeed, the present study observed lower uPAR expression on K562 cells and increased expression in multidrug-resistant K562/ADM cells. Gutova et al (24) investigated the role of UPAR and the multi-drug resistance gene in several types of human cancer. Whether uPAR overexpression is responsible for leukemia multidrug resistance still requires additional investigation. Future studies will need to additionally evaluate the effect and mechanism of $\mathrm{uPAR}^{+}$expression in correlation with treatment resistance in patients with leukemia, particularly whether the downregulation of UPAR expression would influence MDR1 expression to ameliorate chemosensitivity or improve treatment response.

In summary, the present study revealed that the level of plasma suPAR represents a useful marker for leukemia subclassification. Plasma suPAR and/or cell surface uPAR expression associates with chemotherapy resistance in patients with leukemia.

\section{Acknowledgements}

The present study was supported by the Project for Health Research of Gansu Province (grant no. GWGL2013-23).

\section{References}

1. Montuori N and Ragno P: Multiple activities of a multifaceted receptor: Roles of cleaved and soluble uPAR. Front Biosci (Landmark Ed) 14: 2494-2503, 2009.

2. Rønne E, Pappot H, Grøndahl-Hansen J, Høyer-Hansen G, Plesner T, Hansen NE and Danø K: The receptor for urokinase plasminogen activator is present in plasma from healthy donors and elevated in patients with paroxymal nocturnal haemoglobinuria. Br J Haematol 89: 576-581, 1995.

3. Stephens RW, Pedersen AN, Nielsen HJ, Hamers MJ, Høyer-Hansen G, Rønne E, Dybkjaer E, Danø K and Brünner N: ELISA determination of soluble urokinase receptor in blood from healthy donors and cancer patients. Clin Chem 43: 1868-1876, 1997.

4. Donadello K, Scoletta S, Covajes C and Vincent JL: suPAR as a prognostic marker in sepsis. BMC Med 10: 2, 2012.

5. Tzanakaki G, Paparoupa M, Kyprianou M, Barbouni A, Eugen-Olsen J and Kourea-Kremastinou J: Elevated soluble urokinase receptor values in CSF, age and bacterial meningitis infection are independent and additive risk factors of fatal outcome. Eur J Clin Microbiol Infect Dis 31: 1157-1162, 2012.

6. Y1lmaz G, Köksal I, Karahan SC and Mentese A: The diagnostic and prognostic significance of soluble urokinase plasminogen activator receptor in systemic inflammatory response syndrome. Clin Biochem 44: 1227-1230, 2011.
7. Enocsson H, Sjöwall C and Wetterö J: Soluble urokinase plasminogen activator receptor-a valuable biomarker in systemic lupus erythematosus? Clin Chim Acta 444: 234-241, 2015.

8. Toldi G, Bekő G, Kádár G, Mácsai E, Kovács L, Vásárhelyi B and Balog A: Soluble urokinase plasminogen activator receptor (suPAR) in the assessment of inflammatory activity of rheumatoid arthritis patients in remission. Clin Chem Lab Med 51: 327-332, 2013.

9. Eugen-Olsen J, Andersen O, Linneberg A, Ladelund S, Hansen TW, Langkilde A, Petersen J, Pielak T, Møller LN, Jeppesen J, et al: Circulating soluble urokinase plasminogen activator receptor predicts cancer, cardiovascular disease, diabetes and mortality in the general population. J Intern Med 268: 296-308, 2010.

10. Toldi G, Bíró E, Szalay B, Stenczer B, Molvarec A, Rigó J, Vásárhelyi B and Bekõ G: Soluble urokinase plasminogen activator receptor (suPAR) levels in healthy pregnancy and preeclampsia. Clin Chem Lab Med 49: 1873-1876, 2011.

11. Ivancsó I, Toldi G, Bohács A, Eszes N, Müller V, Rigó J Jr, Vásárhelyi B, Losonczy G and Tamási L: Relationship of circulating soluble urokinase plasminogen activator receptor (suPAR) levels to disease control in asthma and asthmatic pregnancy. PLoS One 8: e60697, 2013.

12. Odden N, Henriksen T and Mørkrid L: Serum soluble urokinase plasminogen activator receptor (suPAR) in early pregnancy prior to clinical onset of preeclampsia. Acta Obstet Gynecol Scand 91: 1226-1232, 2012.

13. Pappot H, Høyer-Hansen G, Rønne E, Hansen HH, Brünner N, Danø K and Grøndahl-Hansen J: Elevated plasma levels of urokinase plasminogen activator receptor in non-small cell lung cancer patients. Eur J Cancer 33: 867-872, 1997.

14. Høgdall CK, Christensen IJ, Stephens RW, Sørensen S, Nørgaard-Pedersen B and Nielsen HJ: Serum tetranectin is an independent prognostic marker in colorectal cancer and weakly correlated with plasma suPAR, plasma PAI-1 and serum CEA. APMIS 110: 630-638, 2002.

15. Begum FD, Høgdall EV, Riisbro R, Christensen IJ,Engelholm SA, Jørgensen M, Pedersen BN and Høgdall CK: Prognostic value of plasma soluble urokinase plasminogen activator receptor (suPAR) in Danish patients with recurrent epithelial ovarian cancer (REOC). APMIS 114: 675-681, 2006.

16. Ostrowski SR, Piironen T, Høyer-Hansen G, Gerstoft J, Pedersen BK and Ullum $\mathrm{H}$ : High plasma levels of intact and cleaved soluble urokinase receptor reflect immune activation and are independent predictors of mortality in HIV-1-infected patients. J Acquir Immune Defic Syndr 39: 23-31, 2005.

17. Wittenhagen P, Kronborg G, Weis N, Nielsen H, Obel N, Pedersen SS and Eugen-Olsen J: The plasma level of soluble urokinase receptor is elevated in patients with Streptococcus pneumoniae bacteraemia and predicts mortality. Clin Microbiol Infect 10: 409-415, 2004.

18. Koch A, Voigt S, Kruschinski C, Sanson E, Dückers H, Horn A, Yagmur E, Zimmermann H, Trautwein C and Tacke F: Circulating soluble urokinase plasminogen activator receptor is stably elevated during the first week of treatment in the intensive care unit and predicts mortality in critically ill patients. Crit Care 15: R63, 2011.

19. Rabna P, Andersen A, Wejse C, Oliveira I, Gomes VF, Haaland MB, Aaby P and Eugen-Olsen J: High mortality risk among individuals assumed to be TB-negative can be predicted using a simple test. Trop Med Int Health 14: 986-994, 2009.

20. Haupt TH, Petersen J, Ellekilde G, Klausen HH, Thorball CW, Eugen-Olsen J and Andersen O: Plasma suPAR levels are associated with mortality, admission time, and Charlson Comorbidity Index in the acutely admitted medical patient: A prospective observational study. Crit Care 16: R130, 2012.

21. Mustjoki S, Alitalo R, Stephens RW and Vaheri A: Blast cell-surface and plasma soluble urokinase receptor in acute leukemia patients: Relationship to classification and response to therapy. Thromb Haemost 81: 705-710, 1999.

22. Graf M, Reif S, Hecht K, Pelka-Fleischer R, Pfister K and Schmetzer H: High expression of urokinase plasminogen activator receptor (UPA-R) in acute myeloid leukemia (AML) is associated with worse prognosis. Am J Hematol 79: 26-35, 2005.

23. Livak KJ and Schmittgen TD: Analysis of relative gene expression data using real-time quantitative PCR and the 2(-Delta Delta C(T)) method. Methods 25: 402-408, 2001.

24. Gutova M, Najbauer J, Gevorgyan A, Metz MZ, Weng Y, Shih CC and Aboody KS: Identification of uPAR-positive chemoresistant cells in small cell lung cancer. PLoS ONE 2: e243, 2007. 
25. Lomholt Af, Christensen IJ, Hoyer-Hansen G and Nielsen HJ: Prognostic value of intact and leaved formof the urokinase plasminogen activator receptor in a rettospective study of 518 coloreta cancer patients. Act Oncol 49: 805-811, 2010.

26. Kjellaman A, Akre O, Gustafsson O, Hansen GH, Lilja H, Norming U, PiironenT and Törnblom M: Soluble urokinase plasminogen activator receptor as prognositic marker in men participating in prostate cancer rescreening. J Intern med 269 299-305, 2011.
27. Kaya S, Köksal I, Mentese A, Sönmez M, Sümer A, Yıldırım SS and Yilmaz G: The significance of serum urokinase plasminogen activation receptor (suPAR) in the diagnosis and follow-up of febrile neutropenic patients with hematologic malignancies. Int J Infect Dis 17: e1056-e1059, 2013.

28. Jardí M, Inglés-Esteve J, Burgal M, Azqueta C, Velasco F, López-Pedrera C, Miles LA and Félez J: Distinct patterns of urokinase receptor (uPAR) expression by leukemic cells and peripheral blood cells. Romb Haemost 76: 1009-1019, 1996. 